\title{
The Shaytor Apatite-Magnetite Deposit in the Kashmar-Kerman Tectonic Zone (Central Iran): A Kiruna-Type Iron Deposit
}

\author{
Dariush Esmailiy, Saeid Zakizadeh*, Fatemeh Sepidbar, Ali Kanaanian, \\ Shojaaddin Niroomand \\ Department of Geology, University of Tehran, Tehran, Iran \\ Email: *zakizadeehsarabi@ut.ac.ir
}

Received 18 May 2016; accepted 22 August 2016; published 25 August 2016

Copyright (C) 2016 by authors and Scientific Research Publishing Inc.

This work is licensed under the Creative Commons Attribution International License (CC BY).

http://creativecommons.org/licenses/by/4.0/

(c) (i) Open Access

\section{Abstract}

The Shaytor apatite-rich iron deposit is located in the Kashmar-Kerman tectonic zone in the central of the Iranian plat, which is an important polymetallic belt in Iran. The ore bodies are interbedded with the upper inferacaamberian calc-alkaline igneous rocks that show well-preserved porphyritic and volcaniclastic textures. The iron ores have massive, disseminated, and brecciated structures. Magnetite from the Shaytor deposit is low in $\mathrm{Ti}_{\left(\mathrm{TiO}_{2}\right.}=$ up to $\left.0.70 \mathrm{wt} . \%\right)$ and different ore types show similar rare earth element (REE) and trace element-normalized patterns with weakto-moderate enrichment in light REE and negative Eu anomalies, indicating a common source and genesis. The similar REE patterns for the magnetite and volcanic basaltic host rocks suggest their close genetic linkage and support a magmatic origin for the deposit. The Shaytor deposit shows the typical characteristics of Kiruna-type deposits with regard to the mineral assemblages, ore texture and structure, and the apatite and magnetite geochemistry. We propose that the Kiruna-type Shaytor apatite-rich iron deposit was derived from Fe-P-rich melt through liquid immiscibility and the activity of hydrothermal fluids.

\section{Keywords}

Magnetite-Apatite, Shaytor Iron Deposit, Kashmar-Kerman Tectonic Zone

\section{Introduction}

Magnetite deposits that are related with magmatic rocks in volcano-plutonic belt occur worldwide range in age

\footnotetext{
${ }^{*}$ Corresponding author.
}

How to cite this paper: Esmailiy, D., Zakizadeh, S., Sepidbar, F., Kanaanian, A. and Niroomand, S. (2016) The Shaytor Apatite-Magnetite Deposit in the Kashmar-Kerman Tectonic Zone (Central Iran): A Kiruna-Type Iron Deposit. Open Journal of Geology, 6, 895-910. http://dx.doi.org/10.4236/ojg.2016.68068 
from Proterozoic to Cenozoic. The majority of these deposits are genetically related to intermediate calc-alkaline magmas in a volcano-plutonic arc. The origin of these deposits has been the subject of numerous studies, but debate continues, with both magmatic models that call for immiscible iron oxide-rich melts (e.g., [1] [2]) and hydrothermal models being proposed (e.g., [3]). The Kiruna-type magnetite mineralization, hosted in intermediate-to-felsic volcanic-subvolcanic rocks, is one of the best-known types of this deposit on account of the size and economic value, with individual deposits, containing hundreds of millions of tons of high-grade iron ore and variable amounts of apatite ([1] [4]). The Bafq mining district is in the in Central Iran and hosts important "Kiruna-type" magnetite-apatite deposits. Occurrence of voluminous Cadomian (Ediacaran-Cambrian) subductionrelated magmatism in basement central Iran, Turkey and Greece confirms for formation of an Andean-type active margin all along the northern (proto-Tehyan) margin of the Gondwana Supercontinent ([6]-[8]). In Central Iran, Cadomian magmatism Andean-type active margin is known as Kashmar-Kerman tectonic zone (KKTZ) which is dominated by granitic to tonalitic gneiss of Ediacaran-Cambrian ages [9]-[11]. Ediacaran-Cambrian magmatism of the Cadomian belt in the KKTZ is suggested to reflect widespread continental arc magmatism along the northern margin of Gondwana (e.g., [12]). The Shaytor Fe deposites, in Bafq district, are located at Kashmar-Kerman Tectonic Zone [9]. The Shaytor area of Iran is unknown iron-apatite province and contains numerous major hydrothermal iron deposits associated to Early Cambrian volcano-sedimentary systems. Textural, mineral compositional and whole rock chemistry data are also used to better define the processes and mechanisms that take placed in forming iron-apatite in Sahytor. However, no work on the Shaytor mining district has been published until now. This paper aims to find of 1) detailed review of the geological characteristics of the iron deposits in the Shaytor area; 2) interpreting the iron metallogenesis; and 3) comparing these iron deposits in the Shytor basin with the Kiruna-type iron deposit in terms of geology, alteration and metallogenic processes.

\section{Geological Setting}

\subsection{General View}

Central Iranian microplate is an assemblage of several Precambrian fragments of Gondwanaland. It is bordered by Alborz and Kopeh-Dagh ranges to the north, Zagros and Makran ranges to the west and south, and the East Iran Ranges to the east (Figure 1(a)). Central Iranian microplate consists, from east to west, of three major crustal domains: the Lut Block, Tabas Block and the Yazd Block. These Blocks are separated by a series of intersecting regional-scale faults (Figure 1(a) and Figure 1(b)). The Tabas and Yazd Blocks are separated by a more than 1000-km-long, and up to 80-km-wide, arcuate and structurally complex belt composed of variably deformed supracrustal rocks, i.e. the KKTZ [9]. Recent work by [9] showed that the KKTZ represents an active continental-margin environment and does not show primary alkaline affinities attributable to intra-plate magmatism. It hosts the most of Bafq Fe mining district such as Chador Malu, Se Chahun, Choghart, Esfordi and Shaator. (Figure 1(b)). The Shaytor Fe deposite is located at in east of Kerman-Kashmar tectonic zone and Bafq metallogenic district (Figure 1(b)).

\subsection{Regional Geology}

The Precambrian basement rocks of Iran seem to be a continuation of the Arabian shield and form from granite-gneisses and migmatite which have been reported from the Bafq to Robate-Poshte-Badam region in Central Iran [13]. Their composition varies from granite-gneiss to biotite gneiss with disthene and garnet. These include the Chapedony and Boneh-shurow Complexes. The mentioned basement complexes are overlain by metamorphic rocks, up to amphibolite facies, which include biotite schists, amphibolites, quartzitic schists and marbles, often containing garnet and andalusite. In the stratigraphic division of Iran, the "Infracambrian" is applied to the time interval between the Late Precambrian and the Cambrian [14]. In Central Iran, the KKTZ has Infracambrian age and consists of a complex set of volcano-sedimentary rocks which is very extensive from Poshte-Badam to Zarand and hosts the most important iron oxide-apatite, $\mathrm{Pb}-\mathrm{Zn}$ and $\mathrm{U}$ ore deposits in Iran (Figure 1(b)).

The volcanogenic rocks vary from acid to basic in composition, and include rhyolite, agglomeratic tuff, splitic lava and diabase, and most are subjected to widespread alkaline metasomatism. The sedimentary rocks consist of dolomites, dolomitic limestones and evaporites as Rizu and Desu series [15] and [16]. The main part of Shaytor Fe deposite in east of KKTZ has formed from Rizu formation. It consists of volcano-plutonic complexs including basalt, andesite, trachyte, rhyodacite, rhyolite as well as granite and diorite (Figure 1(c)) which having 

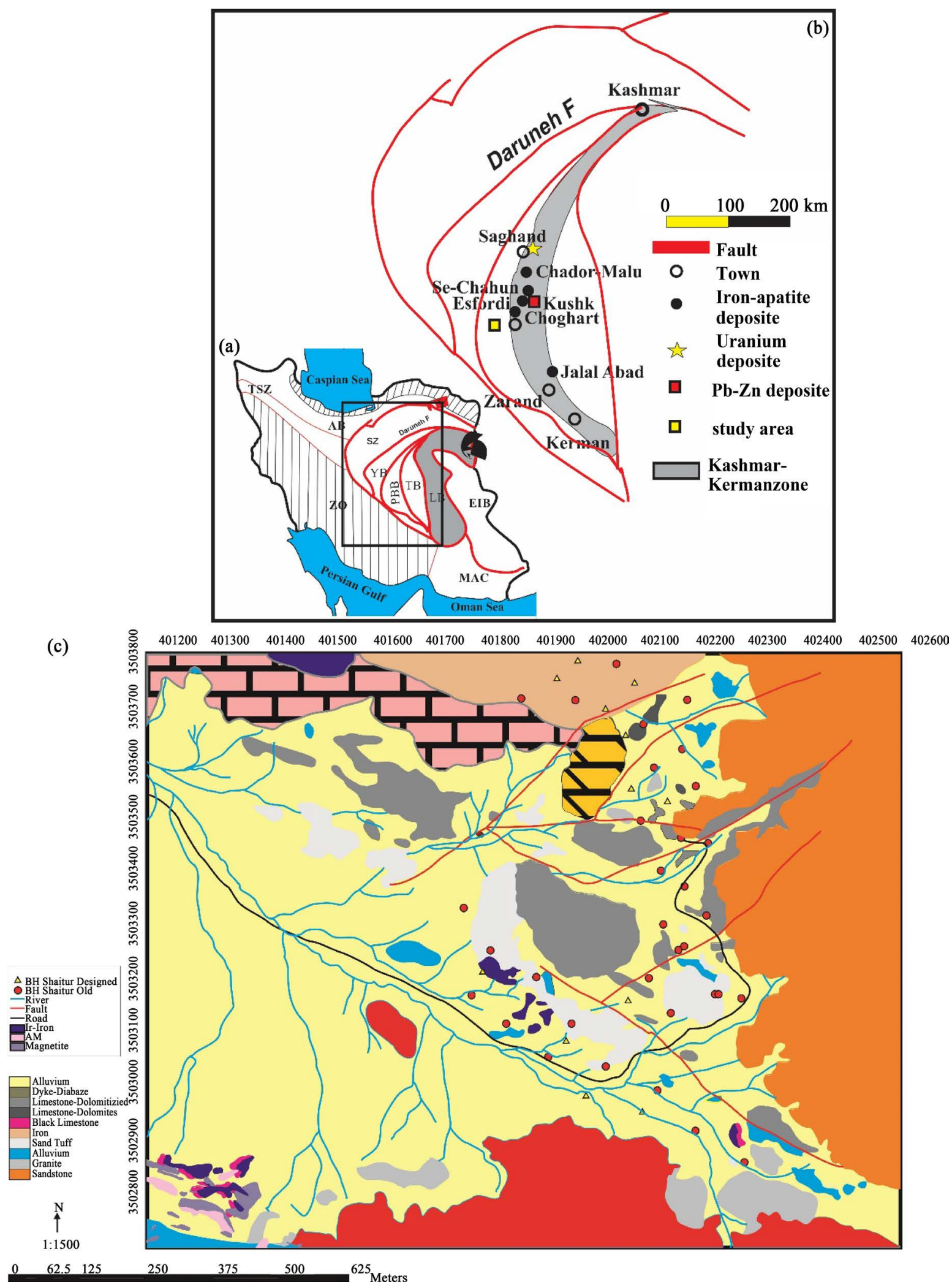

Figure 1. (a) and (b) Structural map of eastern Central Iran (modified after [9] and [19]). The arcuate Kashmar-Kerman zone includes the Bafq district and most important iron oxide-apatite deposits; (c) Geological map showing the relationship between wall rocks and ore bodies of the Shaytor apatite-rich magnetite deposit. 
been subject to widespread alkaline metasomatism (K-feldsparization and albitization; e.g., [17]). Plutonic bodies of mostly granitic composition (locally associated with diorite and gabbro-diorite dikes or sills) intruded into the volcano-sedimentary rocks as well as the Upper Precambrian metamorphic rocks, which are quite common in Central Iran [18]. [19] suggests that these rocks are calc-alkaline intrusions affected by widespread sodic alteration (albitization), and proposes an evaporitic source for Na. The most important of plutonic rocks is Zarigan, the Chador-Malu granites. [9] and [20] defined an age of $525 \pm 7 \mathrm{Ma}, 529 \pm 16 \mathrm{Ma}$ (U-Pb on zircon) and 527 - $539 \mathrm{Ma}$ (U-Pb apatite age) for the Zarigan, the Chador-Malu granites and major iron oxide-apatite deposits in the Bafq district, respectively. These ages confirm that mineralization have been related to magmatic rocks of the Bafq district. There are three areas with a dense distribution of magnetite or hematite deposits in the Bafq NNW-elongated basin (Figure 1): the Jalal Abad deposit in the South; Choghart, Esfordi and Se-Chahun, and Shaytor deposits in the center; and the Chador-Malu deposits in the north. This mineralizations are closely associated with the subvolcanic plutons. The Shaytor mining region is in the Early Cambrian Kashmar-Kerman volcano-plutonic arc in Central Iran which hosts important "Kiruna-type” magnetite-apatite deposits [19]. The ore shows different textures from fine grained to coarse grained. The mineral assemblages in the ore are mainly quartz-magnetite, apatite-magnetite, quartz-apatite-magnetite. Massive, banded and brecciated ores are identified based on their structure. The massive ores consist predominantly of magnetite, hematite and martite, with minor apatite and quartz (Figure 2(a)). These ores contains, miarolitic and amygdaloidal structures (Figure 2(b)) filled by quartz and calcite crystals, which are also common in the Kiruna-type deposit in Chile and Sweden and porphyry-type iron deposits in China ([4] and [1]). The banded ore is characterized by magnetite bands alternating with apatite (Figure 2(c)) or host rock bands of 2 to $3 \mathrm{~mm}$ to a few centimeters thick. The apatite bands (up to several centimeters wide) are mostly pure with minor magnetite or hematite, whereas the magnetite bands contain variable concentrations of apatite. brecciated ores consist of some breccia clasts have corrosion rims cemented by magnetite (Figure 2(d)). Some breccias contain veinlets of magnetite.

\section{Petrography}

Magnetite is the dominant iron oxide mineral in the Shaytor deposit, along with minor hematite, martite, limo-

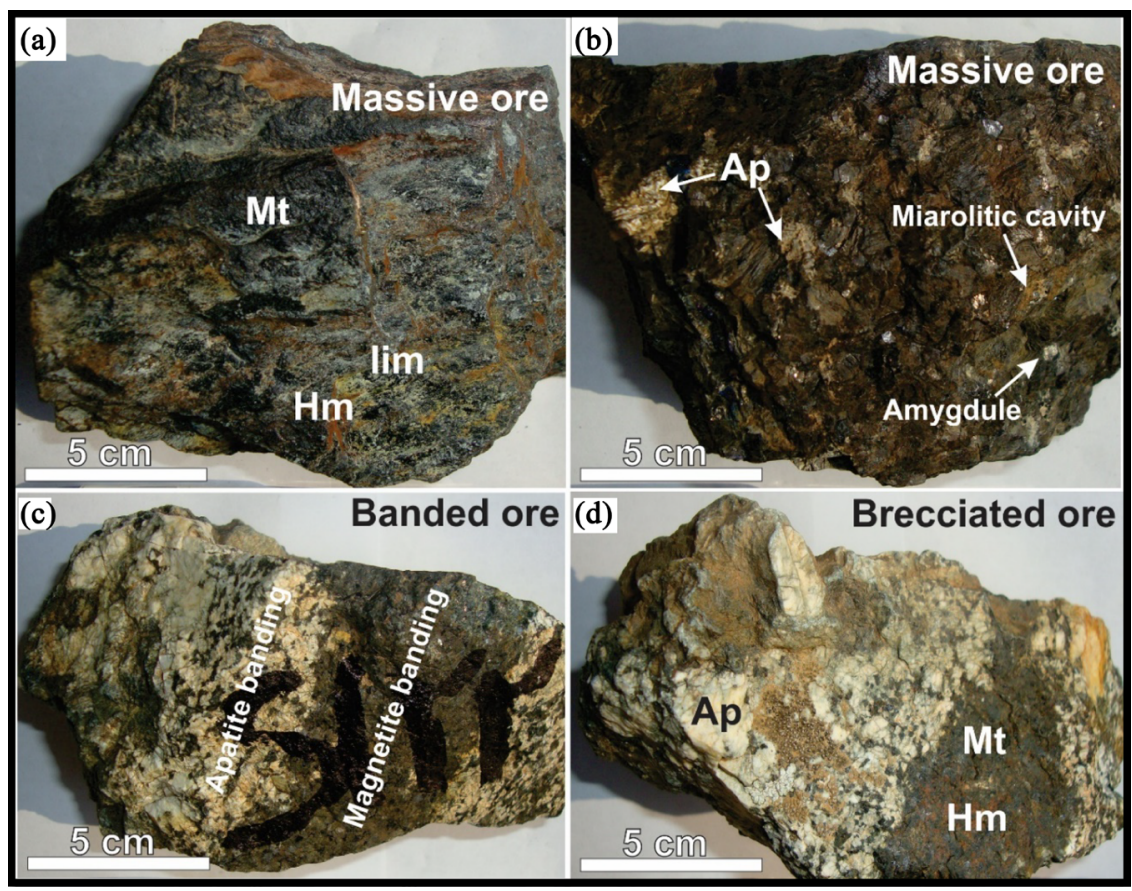

Figure 2. Photographs of ore types. (a) Magnetite, hematite and ilmenite in massive ore; (b) Miarolitic and amygdaloidal structures filled by quartz and calcite crystals in massive ore; (c) Banded iron ore showing magnetite (black) and apatite (white) parts; (d) Brecciated ore consisting of apatite fragments cemented by magnetite. Mt: magnetite; Hm: hematite; Iim: limonite; Ap: apatite. 
nite, gohotite, apatite and hematite. Magnetite is euhedral to subhedral and 0.06 to $3 \mathrm{~mm}$ in diameter in the various ore types. Two forms of magnetite have been identified. The first form (I Mt) consists of fine-grained anhedral crystals in various types of ore, and the second form (II Mt) consists of subhedral to euhedral coarse crystals in veins and veinlets cutting I Mt and show cataclastic texture (Figure 3(a) and Figure 3(b)). Apatite is found throughout the massive, banded and bressiated ore bodies. In massive occurs locally in in veins within the ores. The apatite is white, and occurs either as sporadic grains or as relatively pure apatite veins in varying proportions with magnetite. Minor pyrite is sparsely distributed in massive ores and in veins within the ores. Two forms of pyrite have been identified (Figure 3(c) and Figure 3(d)). The first form (PyI) consists of fine-grained anhedral crystals in various types of apatite, the second form (PyII) consist of subhedral to anhedral coarse crystals with apatite, ghohtite and the third form. Quartz, albite, and mica are the dominant gangue minerals.The igneous rocks of the Shaytor Fe deposite can be generally classified into two main groups, plutonic to hypabyssal rocks, and their equivalents volcanics. The plutonic rocks are mainly of granitic composition. However, locally diorites are also observed. Most of the igneous rocks, especially volcanics, have suffered from extensive alteration and their primary composition has been obscured by widespread sodic-potassic alteration. About 40 thin sections of Shaytor granite, diorite, basalt, andesite, trachydacite, dacite-rhyodacite and rhyolite were examined.

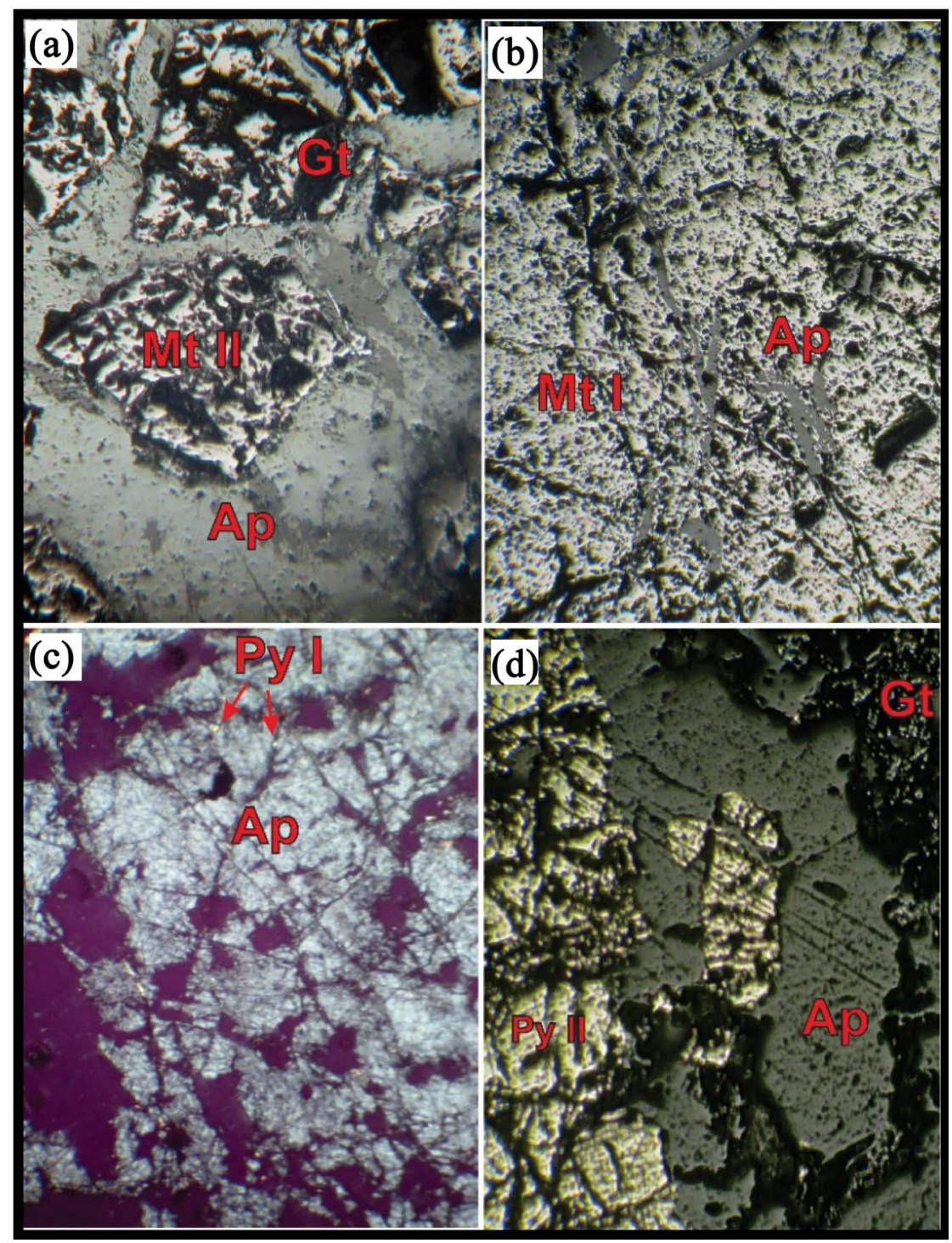

Figure 3. Photographs of minerals of the Shaytor apatite-rich magnetite ores. (a) and (b) Forms of minerals in the ore deposit; (c) First-generation pyrite (py I) distributed randomly in coarse-grain apatite; (d) Second-generation pyrite with ap and Gt. 
The granites are predominant and include plagioclase, alkali-feldspar (orthoclase and microcline), quartz, amphibole, biotite set in microgranular to granophyre textures. Plagioclase is coarse-grained (up to 2) and locally altered into sericite. Apatite, zircon, titanite, and iron oxides are minor phases while chlorite, epidote and sericite are secondary components. The diorites have ophitic to granular texture including plagioclase, amphibole, clinopyroxene and apatite. Titanite is accessory mineral phases in diorite while chlorite, epidote, sericite and termolite are secondary components. The basalts have fine grain to porphyritic texture consist of plagioclase and amphibole. Some place, plagioclase and amphibole show intergranular texture. The trachyandesite has grayish-pinkish white to light brown color and contains up to 25 vol.\% phenocrysts. Plagioclase (12 - 15 vol.\%) and k-feldspar (7 - 10 vol.\%) are common phenocrysts accompanied by chlorite (1 - 3 vol.\%) and epidote (2 - 4 vol. \%), set in a microlithic-porphyritic textures. Plagioclase crystals occur in a variety of sizes. The smaller plagioclase grains ( $0.05-0.1 \mathrm{~mm}$ long) are elongated and typically show albite twinning, while the larger crystals are blocky (0.1-2.0 mm long) and display well-developed, generally plateau-style zoning. The dacite is grayish white color with a massive structure and porphyritic to hyaloporphyritic texture. The phenocrysts are mainly large plagioclase (15 - 20 vol.\%), K-feldespar ( 5 vol.\%), quartz (1 - 2 vol.\%) and biotite with a grain size of $0.25-2.00 \mathrm{~mm}$, set in a matrix $(<0.2 \mathrm{~mm})$ that is mainly composed of quartz and feldspar. Plagioclase is present as randomly distributed subhedral tabular crystal that has been altered to kaolinite and sericite. Quartz is nearly rounded and shows undulating extinction. Plagioclase phenocrysts are oscillatory zoned and consist of repetitive normal zoning patterns. Rhyolites have a same mineralogy with dacite with more quartz in modal. They contain quartz, plagioclase and k-feldespar.

\section{Analytical Method}

All major element compositions of minerals were obtained by electron microprobe analysis (EMPA) in Iran Mineral Processing Research Center (IMPRC). Analyses were performed at an accelerating voltage of $20 \mathrm{kV}$ and beam diameter of $5 \mu \mathrm{m}$, and a beam current and counting time of $20 \mathrm{nA}$ and $10-15 \mathrm{~s}$, respectively. A range of natural and synthetic standards was used. The analytical precision for most elements was better than $0.5 \%$. Analysis of major and trace and rare earth elements (REEs) were performed at the SGS using ICP-AES and ICP-MS the inductively coupled plasma (ICP-MS) method on powder from host rock and magnetite whole rocks.

\section{Results}

\subsection{Mineral Chemistry}

\section{Magnetite}

The representative results of EMPA and LA-ICP-MS analyses for magnetite are presented in Table 1 and 3 The anhedral and euhedral magnetite in the Shaytor is Fe-rich with average $\mathrm{FeO}_{\mathrm{T}}$ abundances from 98.4 wt.\% to 101.2 wt.\%, low $\mathrm{SiO}_{2}$ contents up to 0.9 wt.\%. They do not show systematic chemical variations from core to rim. Magnetite in the Shaytor contains low MgO (up to 0.29 wt.\%), low $\mathrm{MnO}$ (up to 0.02). In addition, the magnetite contains moderate to low $\mathrm{Al}_{2} \mathrm{O}_{3}$ (up to 0.35 wt.\%). Low abundances of $\mathrm{Al}_{2} \mathrm{O}_{3}, \mathrm{TiO}_{2}$ (up to 0.70 wt.\%) and $\mathrm{MgO}$ in magnetite obtained by EMP indicate insignificant variation due to exsolution of ilmenite and spinel. The composition of the magnetites is consistent with those from Kiruna-type magnetites, which have low $\mathrm{TiO}_{2}$ compositions (usually < 2 wt.\%) [1]. Chondrite-normalized rare earth element (REE) patterns for the magnetite from the Shaytor are characterized by enriched in LREEs relative to HREEs, the LREE/HREE ratios are variable (Table 2; Figure 4).

Magnetites show moderately steep chondrite-normalized patterns with (La/Sm)N ratio 1.61 - 3 and have similar negative Eu anomalies $\left(\mathrm{Eu} / \mathrm{Eu}^{*}=0.18-0.27\right)$. These characteristics are probably related to the existence of apatite because apatite controls the REE budget of the rock. Iron ores were classified by [21] based on the Ni, V, Ti, Fe content. They proposed V vs. Ni, V/Ti vs. Ni/Ti and V/Fe vs. Ti/Fe diagrams for distinguishing the apatite iron ores, titaniferous iron ores and Banded iron formations. Based on these diagrams, the Shaytor magnetite-apatite mineralization classified as apatite iron ores (Figure 5).

\subsection{Host Rock Whole Rock Chemistry}

The major and trace element compositions of the rocks are given in Table 3 and are clearly affected by hydro- 
thermal alteration. They show composition variations reflecting their lithologies from mafic to falsic composition (Figure 6(a)). The silica concentration ranges from 45.16 wt.\% to 71.03 wt.\% (Table 3) and 45.91 wt.\% to 70.20 wt.\% for extrusive and intrusive rocks, respectively. The alkali contents of extrusive rocks vary between 0.1 wt. $\%$ and 2.1 wt. $\% \mathrm{Na}_{2} \mathrm{O}$ and 1.56 wt.\% to 8.14 wt.\% $\mathrm{K}_{2} \mathrm{O}$, while the intrusive rocks have more $\mathrm{Na}_{2} \mathrm{O}$ (from 0.09 wt.\% to 5.14 wt.\%) and less $\mathrm{K}_{2} \mathrm{O}$ values ( $0.1 \mathrm{wt} . \%$ to 4.5 wt.\%) than those of extrusive rocks. Because most of these samples have been affected by extensive alteration, alternatively, the samples have been plotted in the discrimination diagram of [22] which is widely used to discriminate between altered volcanic rocks (Figure 6(a)). In this diagram the more volcanic rocks plot in the rhyodacite-dacite, sub-alkali basalts and trachyte compositional field while the more intrusive rocks plot in the rhyodacite-dacite to sub-alkali basalts field. To distinguish between alkaline and subalkaline suites, the samples have been plotted in a diagram of $\mathrm{Ta} / \mathrm{Yb}$ versus $\mathrm{Th} / \mathrm{Yb}$ (Figure 6(b)). In this diagram, the intrusive as well as extrusive rocks mostly plot in the calcalkaline to shoshonitic field. These rocks are mostly peraluminous with alumina saturation index (ASI (=molar $\mathrm{Al}_{2} \mathrm{O}_{3} /(\mathrm{CaO}$ $+\mathrm{Na}_{2} \mathrm{O}+\mathrm{K}_{2} \mathrm{O}$ ) values more than 1.10 (up to 4.47) except basaltic and gabbroic samples which are plotted in metaluminous field (Figure 6(c)). Also, they mostly plot in the I type granites in a diagram $\mathrm{P}_{2} \mathrm{O}_{5}$ versus silica $\left(\mathrm{SiO}_{2}\right)$ (Figure 6(d)). The felsitic igneous rocks from Shaytor also show affinities to volcanic arc granites in the $\mathrm{Rb}$ against $\mathrm{Y}+\mathrm{Nb}$ diagrams [23] (Figure 6(f)). Chondrite-normalized rare earth element (REE) and primitive mantle normalize patterns for the granitoids and volcanic rock from the Shaytor show two type of trend including 1) mafic rocks with enrichment in light REEs (LREEs) and LILE compared to heavy REEs (HREEs) and HFSE with negative Eu (Figure 7(a)) 2) and falsic rocks with slight enrichments in LREE without Eu anomaly. Also, in a primitive mantle-normalized [24] trace element diagram, magmatic rocks shows depletion in $\mathrm{K}, \mathrm{P}$ and Ti and enrichment in LILE (Figure 7(b) and Figure 7(d)).

Table 1. Representative magnetite compositions determined by electron microprobe.

\begin{tabular}{|c|c|c|c|c|c|c|c|c|c|c|c|c|c|}
\hline Samples & SH1.01 & SH1.02 & SH1.03 & SH1.04 & SH1.05 & SH1.06 & SH1.07 & SH1.08 & SH1.09 & SH1.11 & SH1.12 & SH1.13 & SH1.14 \\
\hline $\mathrm{SiO}_{2}$ & 0.21 & 0.1 & 0.02 & 0.31 & 0.15 & 0.15 & 0.36 & 0.06 & 0.07 & 0.21 & 0.44 & 0.19 & 0.1 \\
\hline $\mathrm{TiO}_{2}$ & 0.16 & 0.28 & 0.21 & 0.13 & 0.19 & 0.21 & 0.28 & 0.15 & 0.12 & 0.27 & 0.21 & 0.2 & 0.1 \\
\hline $\mathbf{A l}_{2} \mathbf{O}_{3}$ & 0.09 & 0.11 & 0.04 & 0.07 & 0.06 & 0.07 & 0.32 & 0.03 & 0.03 & 0.23 & 0.11 & 0.02 & 0.08 \\
\hline $\mathrm{Cr}_{2} \mathrm{O}_{3}$ & 0 & 0 & 0 & 0 & 0.02 & 0 & 0.01 & 0 & 0 & 0 & 0 & 0 & 0 \\
\hline $\mathbf{V}_{2} \mathbf{O}_{3}$ & 0 & 0.66 & 0.09 & 0.09 & 0.11 & 0.1 & 0.4 & 0.12 & 0.1 & 0.14 & 0.09 & 0.12 & 0.06 \\
\hline $\mathrm{Fe}_{2} \mathrm{O}_{3}$ & 65.02 & 65.28 & 68.61 & 65.08 & 67.82 & 65.62 & 64.26 & 68.41 & 67.65 & 65.34 & 65.23 & 66.69 & 66.51 \\
\hline FeO & 30.05 & 30.35 & 31.27 & 30.15 & 31.21 & 30.13 & 30.6 & 31.11 & 30.84 & 30.15 & 30.3 & 30.38 & 30.2 \\
\hline FeOT & 95.08 & 95.63 & 99.89 & 95.23 & 99.04 & 95.76 & 94.86 & 99.53 & 98.49 & 95.5 & 95.54 & 97.07 & 96.72 \\
\hline MnO & 0.02 & 0.02 & 0.01 & 0.02 & 0 & 0.01 & 0 & 0.02 & 0.02 & 0.01 & 0.01 & 0.01 & 0.02 \\
\hline MgO & 0.01 & 0 & 0 & 0 & 0.01 & 0 & 0 & 0 & 0 & 0.01 & 0.05 & 0 & 0 \\
\hline $\mathrm{CaO}$ & 0.01 & 0.04 & 0.06 & 0.1 & 0.07 & 0.07 & 0.05 & 0.07 & 0.02 & 0.34 & 0.38 & 0.35 & 0.16 \\
\hline $\mathrm{ZnO}$ & 0 & 0.1 & 0 & 0.05 & 0 & 0.14 & 0.04 & 0.05 & 0 & 0 & 0.01 & 0.05 & 0 \\
\hline TOTAL & 95.58 & 96.94 & 100.32 & 96 & 99.65 & 96.51 & 96.32 & 100.03 & 98.85 & 96.71 & 96.84 & 98.01 & 97.24 \\
\hline $\mathrm{Si}$ & 0.06 & 0.03 . & 0 & 0.09 & 0.04 & 0.04 & 0.11 & 0.01 & 0.02 & 0.06 & 0.13 & 0.05 & 0.03 \\
\hline $\mathbf{T i}$ & 0.03 & 0.06 & 0.04 & 0.03 & 0.04 & 0.05 & 0.06 & 0.03 & 0.02 & 0.06 & 0.05 & 0.04 & 0.02 \\
\hline Al & 0.03 & 0.04 & 0.01 & 0.02 & 0.02 & 0.02 & 0.12 & 0.01 & 0.01 & 0.08 & 0.045 & 0.007 & 0.02 \\
\hline $\mathbf{V}$ & 0 & 0.16 & 0.02 & 0.02 & 0.02 & 0.02 & 0.1 & 0.02 & 0.024 & 0.03 & 0.02 & 0.03 & 0.01 \\
\hline Fe(iii) & 15.75 & 15.59 & 15.85 & 15.68 & 15.76 & 15.75 & 15.41 & 15.85 & 15.86 & 15.61 & 15.55 & 15.74 & 15.84 \\
\hline $\mathbf{F e}(\mathrm{ii})$ & 8.092 & 8.05 & 8.03 & 8.07 & 8.06 & 8.03 & 8.15 & 8.01 & 8.03 & 8.01 & 8.03 & 7.97 & 7.99 \\
\hline Mn & 0.005 & 0 & 0.002 & 0.005 & 0 & 0.002 & 0 & 0.005 & 0.005 & 0.002 & 0.002 & 0.002 & 0.005 \\
\hline Mg & 0.004 & 0 & 0 & 0 & 0 & 0 & 0 & 0 & 0 & 0.004 & 0.02 & 0 & 0 \\
\hline $\mathrm{Ca}$ & 0.003 & 0.013 & 0.019 & 0.034 & 0.023 & 0.023 & 0.017 & 0.023 & 0.006 & 0.115 & 0.129 & 0.117 & 0.054 \\
\hline Zn & 0 & 0.02 & 0 & 0.01 & 0 & 0.03 & 0.009 & 0.01 & 0 & 0 & 0.002 & 0.01 & 0 \\
\hline TOTAL & 24 & 24 & 24 & 24 & 24 & 24 & 24 & 24 & 24 & 24 & 24 & 24 & 24 \\
\hline
\end{tabular}


Table 2. Representative whole rock chemistry Shaytor magnetite determined by ICP-MS.

\begin{tabular}{|c|c|c|c|c|}
\hline sample & SH-76-400 & SH-75-336 & SH-73-420 & SH-72-340 \\
\hline $\mathrm{SiO}_{2}$ & 13.36 & 13.97 & 5.83 & 10.28 \\
\hline $\mathrm{Al}_{2} \mathrm{O}_{3}$ & 3.09 & 0.64 & 3.48 & 1.35 \\
\hline $\mathrm{P}_{2} \mathrm{O}_{5}$ & 1.56 & 0.31 & 0.47 & 3.11 \\
\hline $\mathrm{K}_{2} \mathrm{O}$ & 0.0243 & 0.11 & 0.02 & 0.08 \\
\hline $\mathrm{CaO}$ & 1.99 & 1.11 & 2.57 & 3.29 \\
\hline $\mathrm{TiO}_{2}$ & 0.0334 & 0.16 & 0.40 & 0.03 \\
\hline $\mathrm{Fe}_{2} \mathrm{O}_{3}$ & 77.2 & 82.57 & 82.3 & 80.6 \\
\hline $\mathrm{MgO}$ & 2.81 & 0.95 & 3.81 & 1.31 \\
\hline $\mathrm{V}_{2} \mathrm{O}_{5}$ & 0.1626 & 0.18 & 0.3 & 0.19 \\
\hline LIO & 0.01 & 0.01 & 0.51 & 0.01 \\
\hline total & 100 & 100. & 99.7 & 100 \\
\hline $\mathrm{Al}$ & 0.76 & 0.23 & 0.5 & 0.2 \\
\hline As & 4.6 & 1.5 & 3.3 & 2.3 \\
\hline $\mathrm{Ba}$ & 11.2 & 13 & 9.2 & 16.2 \\
\hline $\mathrm{Bi}$ & 0.11 & 0.29 & 0.84 & 0.13 \\
\hline $\mathrm{Ca}$ & 1.99 & 1.11 & 1.23 & 2.14 \\
\hline $\mathrm{Ce}$ & 829 & 45.1 & 101 & 452 \\
\hline Co & 23.3 & 29.8 & 37.8 & 4.8 \\
\hline $\mathrm{Cr}$ & 21.5 & 78.3 & 13.3 & 9.6 \\
\hline Cs & 0.14 & 0.23 & -0.05 & 0.08 \\
\hline $\mathrm{Cu}$ & 10.8 & 12.1 & 12.9 & 6.2 \\
\hline Dy & 31.1 & 8.38 & 7.2 & 27 \\
\hline $\mathrm{Er}$ & 14.2 & 3.9 & 3.14 & 14.3 \\
\hline $\mathrm{Eu}$ & 6.25 & 0.46 & 0.97 & 3.05 \\
\hline $\mathrm{Fe}$ & $>15$ & $>15$ & $>15$ & $>15$ \\
\hline Ga & 21.6 & 24.8 & 30.8 & 18.8 \\
\hline $\mathrm{Gd}$ & 68.6 & 8.55 & 10.8 & 44.9 \\
\hline Ge & 0.4 & 0.2 & 0.6 & 0.2 \\
\hline $\mathrm{Hf}$ & 0.43 & 0.28 & 0.22 & 0.2 \\
\hline $\mathrm{Hg}$ & 1.79 & 6.45 & 1.7 & 2.55 \\
\hline Ho & 5.28 & 1.54 & 1.32 & 5.21 \\
\hline In & 0.05 & 0.03 & 0.03 & 0.07 \\
\hline $\mathrm{K}$ & 0.02 & 0.18 & 0.02 & 0.05 \\
\hline $\mathrm{La}$ & 337 & 17.6 & 39.3 & 177 \\
\hline $\mathrm{Li}$ & 14.8 & 25.3 & 7.2 & 8.6 \\
\hline $\mathrm{Lu}$ & 1.01 & 0.43 & 0.31 & 1.07 \\
\hline $\mathrm{Mg}$ & 1.05 & 0.4 & 0.92 & 0.27 \\
\hline Mn & 257 & 321 & 280.8 & 121.6 \\
\hline Mo & 0.41 & 0.84 & 0.33 & 0.31 \\
\hline $\mathrm{Na}$ & 0.03 & 0.02 & 0.02 & 0.02 \\
\hline $\mathrm{Nb}$ & 5 & 5.8 & 5.10 & 4.7 \\
\hline $\mathrm{Nd}$ & 400 & 22.1 & 44.5 & 200 \\
\hline
\end{tabular}




\begin{tabular}{ccccc} 
Continued & & & & \\
\hline $\mathrm{Ni}$ & 45.4 & 51.8 & 51 & 35.6 \\
$\mathrm{P}$ & 0.77 & 0.15 & 0.13 & 0.98 \\
$\mathrm{~Pb}$ & 3 & 3 & 4 & 4 \\
$\mathrm{Pr}$ & 93.2 & 5.25 & 11.6 & 51.5 \\
$\mathrm{Rb}$ & 0.5 & 8.5 & 0.6 & 2.5 \\
$\mathrm{~S}$ & 0.5 & 0.6 & 1 & 0.6 \\
$\mathrm{Sm}$ & 70.6 & 6.89 & 10.1 & 40.6 \\
$\mathrm{Sr}$ & 18.9 & 10.5 & 12.6 & 14.5 \\
$\mathrm{Ta}$ & 0.55 & 0.5 & 0.63 & 0.44 \\
$\mathrm{~Tb}$ & 6.68 & 1.26 & 1.42 & 5.08 \\
$\mathrm{Th}$ & 8.5 & 3.2 & 2.3 & 10 \\
$\mathrm{Ti}$ & 0.14 & 0.14 & 0.17 & 0.13 \\
$\mathrm{Tm}$ & 1.54 & 0.47 & 0.4 & 1.58 \\
$\mathrm{U}$ & 1.5 & 0.8 & 0.8 & 1.4 \\
$\mathrm{~V}$ & 911 & 1373 & 1168 & 1119 \\
$\mathrm{Y}$ & 133 & 34.3 & 28.2 & 137 \\
$\mathrm{Yb}$ & 8.9 & 3.2 & 2.8 & 10 \\
\hline
\end{tabular}

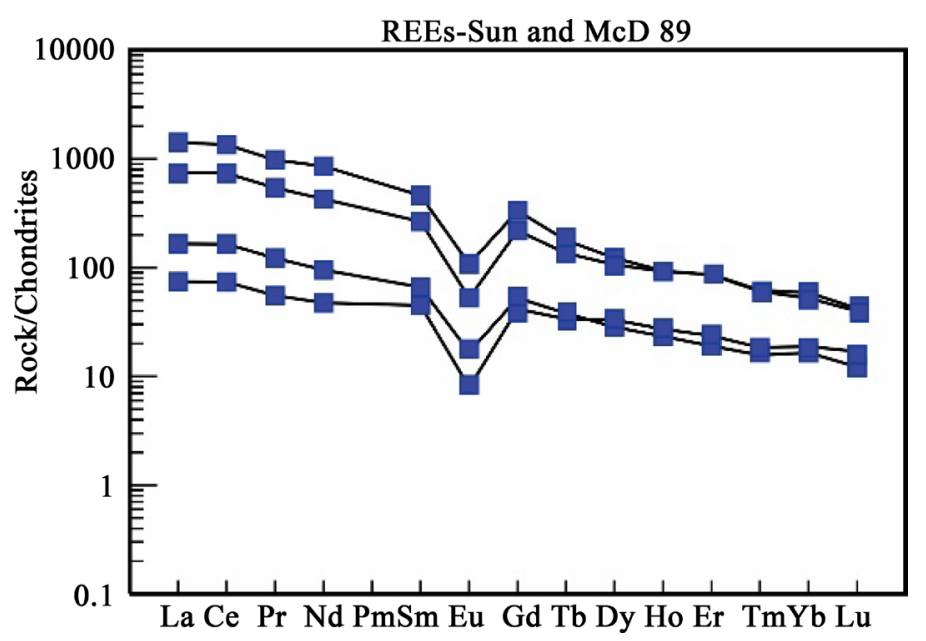

Figure 4. REE pattern in samples from the Shaytor magnetite-apatite mineralization. Normalization data from [24].

\section{Discussion}

\subsection{Source Features}

Major, trace and rare earth element chemistry of the Shaytor rocks demonstrate the significance of crystal frac tionation from parental magma(s). Most of the Shaytor igneous rocks have low $\mathrm{MgO}, \mathrm{Ni}$, and $\mathrm{Cr}$ contents, except basalt and diorite samples, suggesting that they no correspond to primary magma compositions. General fractional crystallization or partial melting trends are indicated by decreasing $\mathrm{TiO}_{2}, \mathrm{MgO}, \mathrm{Fe}_{2} \mathrm{O}_{3}, \mathrm{~V}$, Sc and $\mathrm{Sr}$ concentrations and increasing $\mathrm{K}_{2} \mathrm{O}$ concentration with increasing $\mathrm{SiO}_{2}$ contents in Shaytor igneous rocks (Table 3). These trends can be interpreted to indicate fractionation of amphibole, plagioclase, Fe-Ti-oxides, apatite and zircon. Fractionation of Fe-Ti oxides was important which is consistent with the decrease in $\mathrm{V}$ with increasing $\mathrm{SiO}_{2}$. Also, fractionation of apatite, which may concentrate LREE (e.g. [25]), is compatible with LREE valuse in chondrite normalized patterns (Figure 7). As a mentioned before, according to REE values in the chondrite normalized pattern, the igneous rocks from Shaytor show two trends that show there is two type of magmatism in this region including: (1) primary basalts magmatism with enrichment in LREEs and LILE compared to 
HREEs and HFSE with negative Eu (Figure 7(a)), (2) felsic volcanism and plutonism with evidences for assimilation-fractional crystalization (Figures 7(b)-(d)).

\subsection{Relationship between Magmatism and Iron-Ore Deposits}

Magmatic iron ores were classified by [1] into two groups based on geochemical characteristics which are include: 1) volcanic-exhalative stratiform iron ores and 2) iron-apatite ores and apatite veins. They believed that

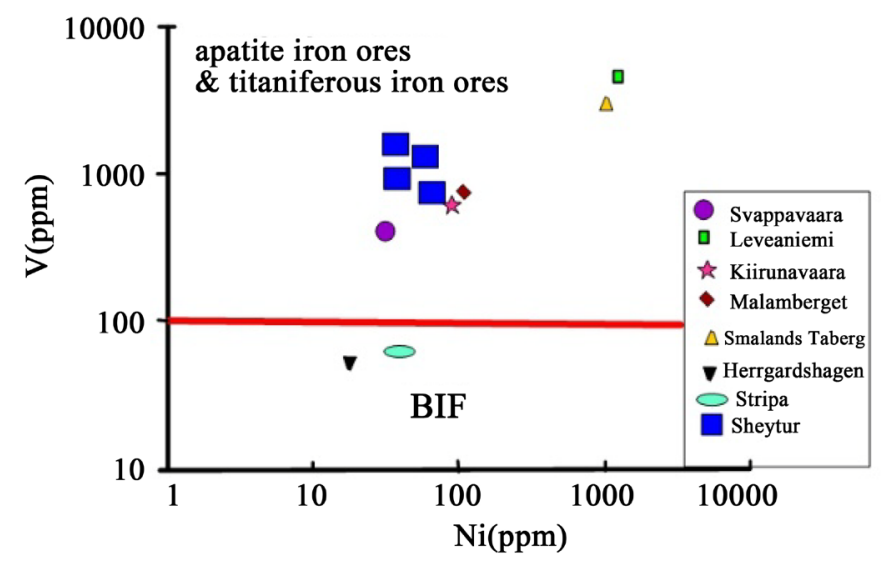

(a)

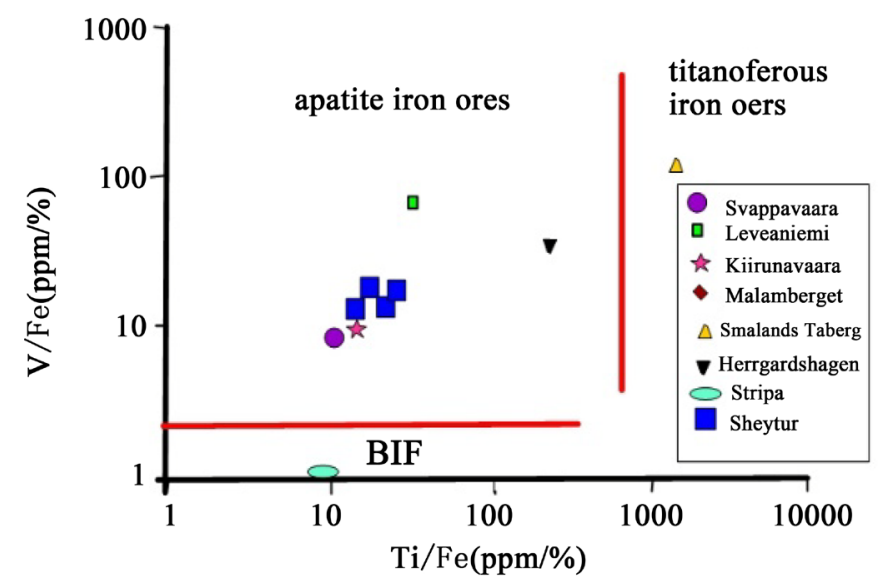

(b)

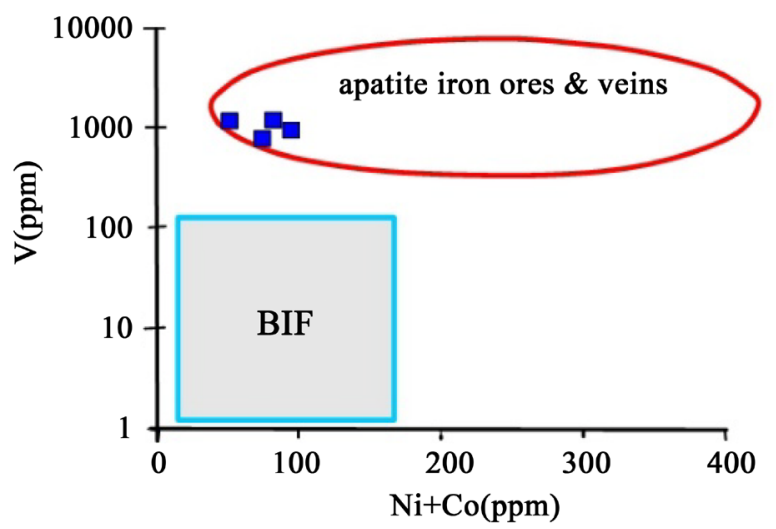

(c)

Figure 5. Location of the Shaytor magnetite-apatite ore samples on the [21] diagrams: (a) V vs. Ni, (b) V/Fe vs. Ti/Fe ratio and (c) V vs. Ni + Co ratio. 
Table 3. Representative whole rock chemistry Shaytor igneous rocks determined by ICP-MS.

\begin{tabular}{|c|c|c|c|c|c|c|c|c|c|c|}
\hline sample & 5a18 & $5 a 43$ & $5 a 44$ & $5 a 45$ & SH-9 & SH-72-439 & SH-72-421 & SH-67-427 & SH-70-70 & SH-5 \\
\hline rock & Basalt & Dacite & Andesite & Dacite & Rhyolite & INTRUSIVE) & Granite & Granite & Granite & \\
\hline $\mathrm{SiO}_{2}$ & 45.2 & 68.94 & 67.57 & 64.99 & 71.03 & 69.44 & 70.2 & 67.18 & 48.7 & 67.1 \\
\hline $\mathrm{Al}_{2} \mathrm{O}_{3}$ & 14.2 & 14.63 & 15.17 & 15.44 & 14.8 & 15.32 & 14.32 & 15.17 & 16.5 & 11.8 \\
\hline $\mathrm{P}_{2} \mathrm{O}_{5}$ & 0.81 & 0.16 & 0.2 & 0.15 & 0.13 & 0.09 & 0.12 & 0.21 & 0.15 & 0.02 \\
\hline $\mathrm{K}_{2} \mathrm{O}$ & 3.15 & 5.69 & 5.61 & 6.65 & 8.14 & 2.71 & 0.8734 & 0.65 & 0.91 & 4.53 \\
\hline $\mathrm{CaO}$ & 2.39 & 0.48 & 1 & 0.92 & 1.48 & 2.29 & 0.64 & 2.57 & 1.76 & \\
\hline $\mathrm{TiO}_{2}$ & 1.17 & 0.55 & 0.71 & 0.66 & 0.07 & 0.69 & 0.5 & 0.86 & 1.12 & 0.05 \\
\hline $\mathrm{Fe}_{2} \mathrm{O}_{3}$ & 23.8 & 4.6 & 5.12 & 6.07 & 0.84 & 2.55 & 3.13 & 4.03 & 11.4 & 6.89 \\
\hline MgO & 4.82 & 1.22 & 1.78 & 2.09 & 0.49 & 0.53 & 0.23 & 0.43 & 5.15 & 3.77 \\
\hline $\mathrm{Na}_{2} \mathrm{O}$ & 0.107 & 1.17 & 0.57 & 0.6 & 2.19 & 3.36 & 4.91 & 5.27 & 2.19 & 0.09 \\
\hline $\mathrm{MnO}$ & 0.1 & 0.01 & 0.02 & 0.02 & 0.01 & 0.0392 & 0.0098 & 0.0746 & 0.19 & 0.0979 \\
\hline LOI & 4.33 & 2.49 & 2.85 & 3.05 & 1.67 & 3.47 & 5.58 & 3.73 & 5.83 & 4.12 \\
\hline Ag & -0.05 & -0.05 & -0.05 & 0.05 & -0.05 & -0.05 & -0.05 & -0.05 & 1.7 & -0.05 \\
\hline $\mathrm{Al}$ & 5.5 & 1.75 & 3.65 & 3.57 & 1.95 & 2.07 & 1.89 & 2.17 & 8.67 & 4.12 \\
\hline $\mathrm{Ba}$ & 570.6 & 603.8 & 786 & 690.8 & 660.4 & 161.2 & 55.4 & 50.6 & 375.2 & 488.2 \\
\hline $\mathrm{Ca}$ & 1.83 & 0.24 & 0.48 & 0.52 & 0.4 & 1.21 & 0.33 & 1.7 & 6.96 & 1.15 \\
\hline $\mathrm{Ce}$ & 220 & 14.1 & 26.1 & 21.2 & 24.3 & 7.72 & 2.51 & 46 & 37.8 & 33.7 \\
\hline Co & 22.7 & 21.3 & 12.4 & 14.1 & 32.7 & 34.4 & 34.6 & 28.8 & 54.7 & 21.9 \\
\hline $\mathrm{Cr}$ & 64.7 & 8.7 & 10.5 & 15.8 & 30.5 & 6.6 & 9 & 14.3 & 242 & 16.2 \\
\hline Cs & 0.97 & 0.54 & 0.78 & 0.69 & 0.47 & 0.89 & 0.19 & 0.47 & 3.61 & 0.9 \\
\hline $\mathrm{Cu}$ & 14.3 & 5.9 & 7.6 & 6.4 & 7.7 & 7.2 & 6.7 & 12.3 & 32.4 & 8.1 \\
\hline Dy & 20.3 & 3.83 & 8.21 & 8.27 & 1.25 & 1.86 & 0.46 & 3.51 & 4.95 & 3.16 \\
\hline $\mathrm{Er}$ & 10.9 & 2.11 & 4.5 & 5.01 & 1.04 & 1.66 & 0.57 & 2.59 & 2.78 & 1.75 \\
\hline $\mathrm{Eu}$ & 2.95 & 0.66 & 1.32 & 1.11 & 0.57 & 0.37 & 0.16 & 0.96 & 1.77 & 0.71 \\
\hline $\mathrm{Fe}$ & $>15$ & 2.91 & 3.73 & 3.86 & 0.42 & 1.82 & 1.68 & 2.45 & 7.7 & 4.16 \\
\hline $\mathrm{Ga}$ & 16.2 & 17 & 21.6 & 23 & 11.9 & 22 & 16.8 & 22.3 & 21 & 14.5 \\
\hline $\mathrm{Gd}$ & 24.1 & 2.68 & 6.74 & 6.16 & 2.12 & 1.64 & 0.53 & 5.19 & 5.89 & 3.98 \\
\hline Hf & 0.75 & 4.58 & 5.24 & 6.15 & 3.89 & 4.47 & 4.85 & 3.93 & 2.06 & 1.55 \\
\hline $\mathrm{Hg}$ & 2.25 & 5.06 & 4.45 & 2.34 & 10.04 & 7.78 & 9.46 & 18.18 & 7.1 & 6.4 \\
\hline Ho & 3.94 & 0.82 & 1.66 & 1.89 & 0.3 & 0.48 & 0.15 & 0.8 & 1.1 & 0.59 \\
\hline In & 0.08 & -0.02 & 0.03 & 0.03 & 0.02 & 0.03 & -0.02 & -0.02 & 0.09 & 0.17 \\
\hline $\mathrm{K}$ & 5.21 & 3.88 & 6.58 & 5.63 & 3.53 & 2.6 & 0.31 & 0.55 & 0.64 & 3.56 \\
\hline $\mathrm{La}$ & 85.8 & 6.1 & 11 & 9.1 & 10.5 & 2.8 & 0.8 & 16.9 & 16.8 & 12.2 \\
\hline $\mathrm{Li}$ & 80.1 & 23.7 & 35.3 & 40.2 & 11.4 & 21.3 & 15.1 & 6.3 & 30.1 & 65.4 \\
\hline $\mathrm{Lu}$ & 0.88 & 0.22 & 0.53 & 0.59 & 0.31 & 0.41 & 0.15 & 0.5 & 0.29 & 0.31 \\
\hline $\mathrm{Mg}$ & 2.75 & 0.75 & 1.18 & 1.33 & 0.08 & 0.32 & 0.14 & 0.26 & 3.84 & 2.44 \\
\hline $\mathrm{Mn}$ & 798 & 112.6 & 198 & 195 & 114 & 302 & 75.8 & 587 & 1449.2 & 758 \\
\hline Mo & 0.98 & 0.89 & 1.1 & 0.85 & 0.45 & 1.49 & 0.73 & 0.96 & 0.96 & 1.87 \\
\hline $\mathrm{Na}$ & 0.08 & 0.99 & 0.42 & 0.45 & 0.11 & 3.14 & 4.34 & 5.14 & 2.11 & 0.07 \\
\hline $\mathrm{Nb}$ & 5.2 & 14.2 & 15.4 & 11.5 & 3.7 & 16.8 & 14.8 & 10.7 & 16.4 & 1.4 \\
\hline $\mathrm{Nd}$ & 97 & 7.71 & 13.4 & 12 & 9.96 & 4.93 & 1.9 & 24.5 & 18.6 & 17.3 \\
\hline $\mathrm{Ni}$ & 29.6 & 1.7 & 1.8 & 1.7 & 3.4 & 3.3 & 3.3 & 4.1 & 118 & 4.1 \\
\hline $\mathrm{P}$ & 0.4 & 0.05 & 0.06 & 0.06 & -0.01 & 0.04 & 0.03 & 0.07 & 0.09 & -0.01 \\
\hline
\end{tabular}




\section{Continued}

\begin{tabular}{|c|c|c|c|c|c|c|c|c|c|c|}
\hline $\mathrm{Pb}$ & 3 & 6 & 7 & 5 & 5 & 3 & 3 & 4 & 173 & 6 \\
\hline $\operatorname{Pr}$ & 25.1 & 1.76 & 3.23 & 2.85 & 2.64 & 1 & 0.33 & 5.69 & 4.45 & 4.17 \\
\hline $\mathrm{Rb}$ & 65.9 & 69.1 & 105 & 95.4 & 84.5 & 49.5 & 2.4 & 5 & 20.3 & 56 \\
\hline Sc & 9 & 2.8 & 6 & 3.7 & 2.6 & 3.2 & 3.6 & 6.2 & 16.2 & 3.9 \\
\hline $\mathrm{Sm}$ & 21 & 2.35 & 4.45 & 3.83 & 2.1 & 1.58 & 0.38 & 5.34 & 4.98 & 4.08 \\
\hline Sn & 12.96 & -3 & 3.43 & 3.04 & 4.07 & 3.73 & 3.64 & 6.15 & -3 & 3.11 \\
\hline $\mathrm{Sr}$ & 50 & 31.6 & 39.9 & 35.8 & 15.4 & 15.4 & 16 & 15.9 & 404 & 23.9 \\
\hline $\mathrm{Y}$ & 84.4 & 17 & 37.4 & 40.2 & 7 & 10.8 & 3.1 & 16.6 & 22.5 & 12.4 \\
\hline Тa & 0.87 & 1.08 & 0.97 & 0.68 & 0.41 & 1.14 & 1.11 & 1.03 & 1.19 & 0.27 \\
\hline $\mathrm{Tb}$ & 3.54 & 0.54 & 1.2 & 1.14 & 0.21 & 0.25 & 0.09 & 0.66 & 0.93 & 0.5 \\
\hline Th & 4 & 3.6 & 9.1 & 9.5 & 13.8 & 4.5 & 1.6 & 5.9 & 1.8 & 14.9 \\
\hline $\mathrm{Ti}$ & 0.44 & 0.31 & 0.32 & 0.3 & 0.04 & 0.27 & 0.23 & 0.3 & 0.89 & 0.03 \\
\hline $\mathrm{Tm}$ & 1.26 & 0.27 & 0.59 & 0.65 & 0.2 & 0.28 & 0.09 & 0.39 & 0.3 & 0.26 \\
\hline $\mathrm{U}$ & 1.5 & 2 & 2.1 & 2.3 & 2.5 & 0.6 & 0.2 & 0.3 & 0.4 & 0.9 \\
\hline V & 169 & 7.9 & 8.7 & 8.6 & 1.9 & 1.3 & 2.4 & 6.3 & 208 & 12.5 \\
\hline $\mathrm{Yb}$ & 7.6 & 1.8 & 3.8 & 4.2 & 1.6 & 2.6 & 0.9 & 3 & 1.9 & 2.2 \\
\hline $\mathrm{Zn}$ & 56.3 & 34.4 & 44.3 & 42.5 & 24.4 & 15.4 & 14.3 & 15.7 & 443 & 42.8 \\
\hline $\mathrm{Zr}$ & 19.3 & 133 & 147 & 174 & 85.3 & 134 & 151 & 114 & 44.7 & 31.1 \\
\hline $\mathrm{Ba}$ & 570.6 & 603.8 & 786 & 690.8 & 660.4 & 161.2 & 55.4 & 50.6 & 375.2 & 488.2 \\
\hline $\mathrm{Ba} / \mathrm{La}$ & 6.65 & 98.9 & 71.4 & 75.7 & 62.9 & 57.6 & 69.25 & 2.99 & 22.3 & 40.01 \\
\hline $\mathrm{Nb}$ & 5.2 & 14.2 & 15.4 & 11.5 & 3.7 & 16.8 & 14.8 & 10.7 & 16.4 & 1.4 \\
\hline $\mathrm{La}$ & 85.8 & 6.1 & 11 & 9.1 & 10.5 & 2.8 & 0.8 & 16.9 & 16.8 & 12.2 \\
\hline
\end{tabular}
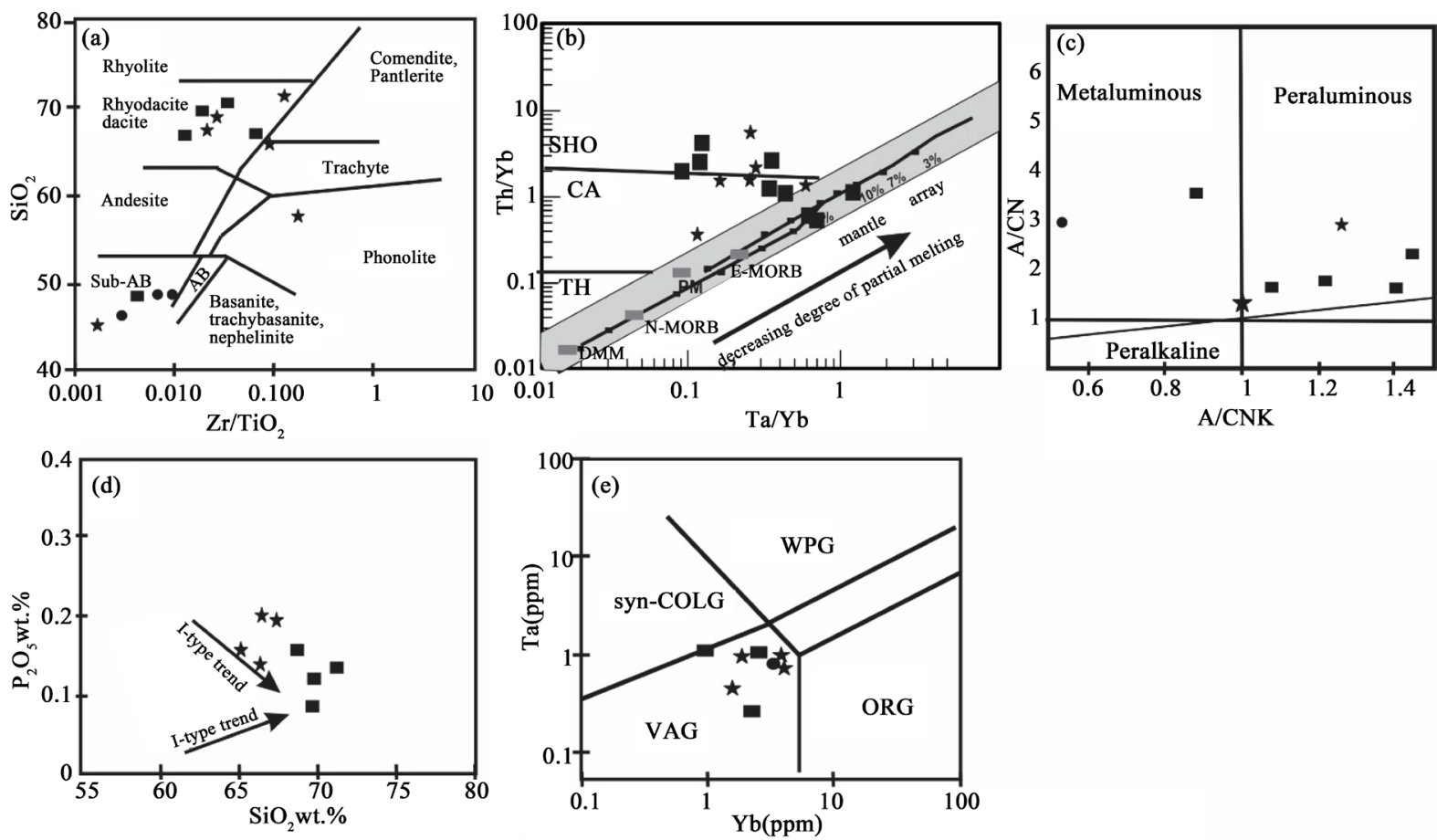

Figure 6. (a) Trace element diagram after [22]; (b) Plot of Th/Yb vs. Ta/Yb [40] for igneous rocks from Shaytor; (c) In the $\mathrm{Al}_{2} \mathrm{O}_{3} / \mathrm{Na}_{2} \mathrm{O}+\mathrm{K}_{2} \mathrm{O}$ (molar) vs. $\mathrm{Al}_{2} \mathrm{O}_{3} /\left(\mathrm{CaO}+\mathrm{K}_{2} \mathrm{O}+\mathrm{Na}_{2} \mathrm{O}\right)$ (molar) diagram [39]; (d) In the $\mathrm{P}_{2} \mathrm{O}_{5}$ vs. SiO $\mathrm{S}_{2}$ diagram, the granitoid and volcanic rocks from Shaytor; (e) Rb vs. Y + Nb geotectonic discrimination diagram [23] for felsitic igneous rocks from Shaytor. 

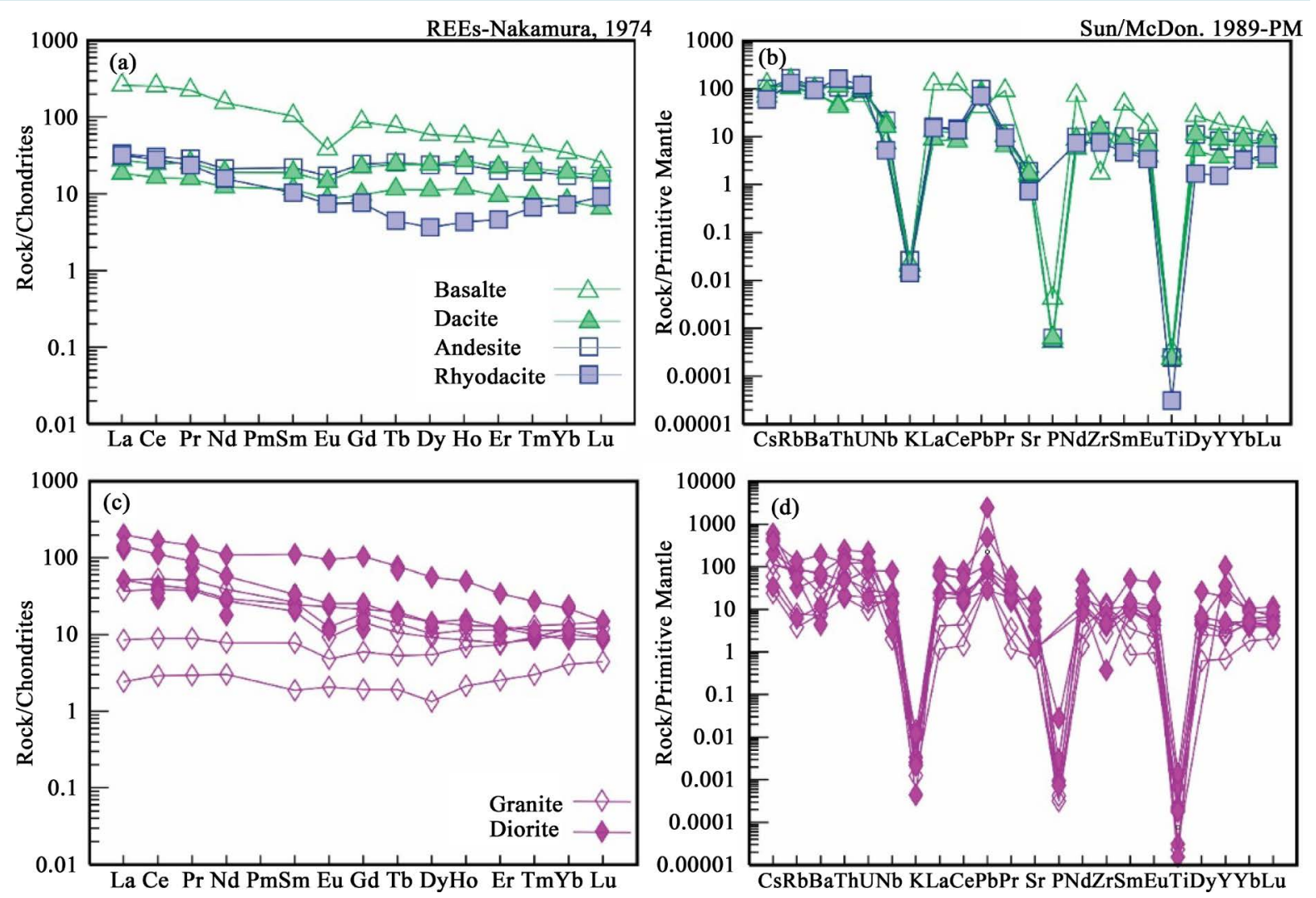

Figure 7. Chondrite-normalized rare earth element (left) and primitive mantle normalized trace element patterns (right) for the volcanic rocks ((a) (b)) and granitoid rocks.

iron-apatite ores demonstrate depletion in Cr (less than 10 ppm), enrichment in V (1000 - 2000 ppm) and depletion in Ti (100 - $1000 \mathrm{ppm}$ occasionally up to $5000 \mathrm{ppm})$. Average content of $\mathrm{Cr}, \mathrm{V}$ and $\mathrm{Ti}$ in the Shaytor magnetite-apatite samples are $30.3 \mathrm{ppm}, 1142.7 \mathrm{ppm}$ and $0.14 \mathrm{ppm}$, respectively. In this base, Shaytor magnetiteapatite mineralization can be classified as iron-apatite ores. Among the iron ores of the world, there is a specific group of occurrences composed of the magnetite-hematite-apatite assemblage (IOA deposits) which are considered as Kiruna-type magnetite-apatite deposits. Rare earth elements (REE) are characteristically elevated in Kiruna-type deposits [26]. Enrichment in REEs is one of the specialties of the Shaytor magnetite-apatite mineralization. REEs content of these samples are high and vary between 56.77- $1087 \mathrm{ppm}$. All of the samples from magnetite ore show a similar pattern with a LREE/HREE fractionation and negative Eu anomaly (Figure 4). These similar REE patterns indicate that these units have a common origin. Moderate LREE/HREE fractionation is a common characteristic of magmatic magnetite-apatite ores connected with calcalkaline rocks. The chondrite-normalized REE patterns (Figure 6(a)) show that the samples from the igneous rocks vary substantially in terms of composition. These samples, except primary basalt, exhibit a weak enrichment of Light REEs compared to Heavy REEs and a relatively flat pattern (Figure 6(a) and Figure 6(c)). The magnetite samples from Shaytor revealed chondrite normalized REE patterns similar to those of the primary basaltic rocks with depleted Eu (Figure 4 and Figure 7(a)). So, it can be find that the Shaytor Fe deposit were generated from basaltic magmas.

\subsection{Comparison with Kiruna-Type Deposit, Sweden}

Kiruna-type deposits contain variable quantities of magnetite-fluorapatite-actinolite ores in volcano-plutonic terrains that range in age from Proterozoic to Cenozoic. The best known, and one of the largest deposits is in the Kiruna region of northern Sweden ([27] [28]), in Missouri, U.S.A., in the Great Bear magmatic zone of Canada [29], in Ningwu basin in the eastern China [30], in the Avnik region of southeastern Turkey [31], and in the Circum-Pacific belt of Chile and Peru ([28]). Iron oxide-apatite deposits of the Shaytor region show some simi- 
larities to the Kiruna-type deposits including (1) according to mineral assemblages, fabric and structure of the iron ores, occurrence of the orebodies and wall rock alteration zones. For example, the iron ores are mainly composed of magnetite or hematite, diopside or actinolite and apatite. These deposits are interpreted as having formed in a rift or extensional environment and mineralization is associated with alkaline magmatism. (2) Geochronological data [9] and [20] show that the time interval between the magmatism and associated mineralization is very short. Alteration, especially albitization, is very pronounced in footwall rocks under the orebodies.

\subsection{Implication of Metallogenic}

As mentioned before, the Shaytor apatite-rich iron deposit is similar to Kiruna-type iron deposits. The origin and enrichment mechanisms of apatite and magnetite in Kiruna-type iron deposits have long been debated, and models proposed include exhalative-sedimentary origin [32] and [26], magmatic origin due to liquid immiscibility [33], and hydrothermal origin [29] and [34]. Recent studies have excluded the exhalative-sedimentary origin hypothesis. The Kiruna-type iron deposits have been interpreted as the product of crystallization of iron oxide magmas derived through immiscible liquid segregation (rich in Ti, P, and Zr) [1] [4] [31] [35]-[38]. It has been hypothesized that silicate liquid immiscibility, caused by 1) crystal fractionation, 2) magma mixing, 3) an abrupt change in oxygen fugacity, and/or 4) an introduction of phosphorus, may lead to the release of an oxide melt from silicate magma [5]. This model has been proposed for some of the magnetite-apatite deposits in the Chilean iron belt [1] and Kiruna [27]. The occurrence of large amounts of the apatite as a gangue mineral is conspicuous in Kiruna-type deposits, such as Shaytor. Also, apatite has spatial association with the iron mineralization in Shaytor. This confirms for Shaytor the model involving immiscible magmatic liquids caused by the introduction of phosphorus. The Shaytor iron deposit was formed from Fe-rich melts (or fluids) that were derived from the mafic magma and channeled along major faults and fractures. The source of the Fe can ultimately be ascribed to the mafic magmas derived from the mantle wedge.

\section{Conclusion}

The Shaytor apatite-rich iron deposit, hosted in calc-alkaline felsic metamorphosed volcanic rocks, is a typical Kiruna-type magnetite deposit. The Shaytor deposit is similar to a Kiruna-type deposit in its mineral assemblages (low-Ti magnetite-apatites with minor pyrite) and ore structure (massive, banded, and brecciated). The magnetite contains low concentrations of Ti. The magnetites, and host primary basaltic rock have similar REE and trace element normalized patterns. The occurrence of large amounts of the apatite as a gangue mineral is conspicuous in Kiruna-type deposits, such as Shaytor. This confirms for Shaytor the model involving immiscible magmatic liquids caused by the introduction of phosphorus. The Fe-rich melts (or fluids) that were derived from the mafic magma and channeled along major faults and fractures was responsible for Source of Fe in Shaytor.

\section{Acknowledgements}

We thank the support of Farhad Ahnadi for help during our field work. We are grateful to the staff of the Iran Mineral Processing Research Center (IMPRC). This study was financially supported by Iranian mines and mining industrial development and renovation organization (IMIDRO).

\section{References}

[1] Nystrom, J.O. and Henriquez, F. (1994) Magmatic Features of Iron Ores of the Kiruna Type in Chile and Sweden: Ore Textures and Magnetite Geochemistry. Economic Geology, 89, 820-839. http://dx.doi.org/10.2113/gsecongeo.89.4.820

[2] Travisany, V., Henriquez, F. and Nystroem, J.O. (1995) Magnetite Lava Flows in the Pleito-Melon District of the Chilean Iron Belt. Economic Geology, 90, 438-444. http://dx.doi.org/10.2113/gsecongeo.90.2.438

[3] Marschik, R. and Fontboté, L. (2001) The Candelaria-Punta del Cobre Iron Oxide Cu-Au (-Zn-Ag) Deposits, Chile. Economic Geology, 96, 1799-1826. http://dx.doi.org/10.2113/96.8.1799

[4] Hou, T., Zhang, Z.C. and Kusky, T. (2011) Gushan Magnetite-Apatite Deposit in the Ningwu Basin, Lower Yangtze River Valley, SE China: Hydrothermal or Kiruna-Type? Ore Geology Reviews, 43, 333-346. http://dx.doi.org/10.1016/j.oregeorev.2011.09.014

[5] Hou, T., Zhang, Z.C., Du, Y.S. and Li, S.T. (2009) Geology of the Gushan Iron Oxide Deposit Associated with Dioritic 
Porphyries, Eastern Yangtze Craton, SE China. International Geology Review, 51, 520-541. http://dx.doi.org/10.1080/00206810902823941

[6] Azizi, H., Chung, S.L., Tanaka, T. and Asahara, Y. (2011) Isotopic Dating of the Khoy Metamorphic Complex (KMC), Northwestern Iran: A Significant Revision of the Formation Age and Magma Source. Precambrian Research, 185, 87-94. http://dx.doi.org/10.1016/j.precamres.2010.12.004

[7] Mahmoud, R.I., Faryad, S.W., Holub, F.V., Košler, J. and Frank, W. (2011) Magmatic and Metamorphic Evolution of the Shotur Kuh Metamorphic Complex (Central Iran). International Journal of Earth Sciences, 100, 45-62. http://dx.doi.org/10.1007/s00531-009-0499-0

[8] Jamshidi Badr, M., Collins, A.S., Masoudi, F., Cox, G. and Mohajjel, M. (2013) The U-Pb Age, Geochemistry and Tectonic Significance of Granitoids in the Soursat Complex, Northwest Iran. Turkish Journal of Earth Science, 22, $1-31$.

[9] Ramezani, J. and Tucker, R.D. (2003) The Saghand Region, Central Iran: U-Pb Geochronology, Petrogenesis and Implications for Gondwana Tectonics. American Journal of Science, 303, 622-665. http://dx.doi.org/10.2475/ajs.303.7.622

[10] Hassanzadeh, J., Stockli, D.F., Horton, B.K., Axen, G.J., Stockli, L.D., Grove, M., Schmitt, A.K. and Walker, J.D. (2008) U-Pb Zircon Geochronology of Late Neoproterozoic-Early Cambrian Granitoids in Iran: Implications for Paleogeography, Magmatism, and Exhumation History of Iranian Basement. Tectonophysics, 451, 71-96. http://dx.doi.org/10.1016/j.tecto.2007.11.062

[11] Shafaii Moghadam, H.S., Khademi, M., Hu, Z., Stern, R.J., Santos, J.F. and Wue, Y. (2013) Cadomian (EdiacaranCambrian) Arc Magmatism in the ChahJam-Biarjmand Metamorphic Complex (Iran): Magmatism along the Northern Active Margin of Gondwana. Gondwana Research, 27, 439-452. http://dx.doi.org/10.1016/j.gr.2013.10.014

[12] Ustaomer, P.A., Ustaomer, T., Collins, A.S. and Robertson, A.H.F. (2009) Cadomian (Ediacaran-Cambrian) Arc Magmatism in the Bitlis Massif, SE Turkey: Magmatism along the Developing Northern Margin of Gondwana. Tectonophysics, 473, 99-112. http://dx.doi.org/10.1016/j.tecto.2008.06.010

[13] Haghipour, A., Valeh, N., Pelissier, G. and Davoudzadeh, M. (1977) Explanatory Text of the Ardekan Quadrangle Map 1: 250,000. Geological Survey of Iran, H8, 114 p.

[14] Stocklin, J. (1968) Structural History and Tectonics of Iran: A Review. American Association of Petroleum Geologists Bulletin, 52, 1229-1258.

[15] Samani, B. (1993) Saghand Formation: A Riftogenic Unit of Precambrian in Central Iran. Geological Survay Iran. Geoscience, 2, 32-45.

[16] Samani, B.A. (1988) Metallogeny of the Precambrian in Iran. Precambrian Research, 39, 85-106. http://dx.doi.org/10.1016/0301-9268(88)90053-8

[17] Daliran, F., Stosch, H.G. and Williams, P. (2007) Multi Stage Metasomatism and Mineralization at Hydrothermal Fe oxide-REE-Apatite Deposits and "Apatitites" of the Bafq District, Central-East Iran. Proceedings of the 9th Biennial Meeting of the Society for Geology Applied to Mineral Deposits, Dublin, 20-23 August 2007, 1501-1504.

[18] Sabet-Mobarhan-Talab, A., Alinia, F. and Asadi, F. (2014) Hydrothermal Overprint of the Chador-MaluKiruna-type Deposit (Bafq District, Central Iran) and Associated REE Mobilization: Evidence from Mineralogy and Geochemistry. International Journal of Economic and Environmental Geology, 5, 1-14.

[19] Torab, F. (2008) Geochemistry and Metallogeny of Magnetite-Apatite Deposits of the Bafq Mining District, Central Iran. Unpublished PhD Thesis, Clausthal University of Technology, Clausthal.

[20] Stosch, H.G., Romer, R.L., Daliran, F. and Rhede, D. (2011) Uranium-Lead Ages Apatite from Iron Oxide Ores of the Bafq District, East-Central Iran. Mineralium Deposita, 46, 9-21. http://dx.doi.org/10.1007/s00126-010-0309-4

[21] Loberg, B.E.H. and Horndahl. A.K. (1983) Ferride Geochemistry of Swedish Precambrian Iron Ores. Mineralium Deposita, 18, 487-504. http://dx.doi.org/10.1007/BF00204493

[22] Winchester, J.K. and Floyd, P.A. (1997) Geochemical Differentiation of Different Magma Series and Their Differentiation Product Using Immobile Elements. Chemical Geology, 20, 325-343. http://dx.doi.org/10.1016/0009-2541(77)90057-2

[23] Pearce, J.A., Harris, N.B.W. and Tindle, A.G. (1984) Trace Element Discrimination Diagrams for the Tectonic Interpretation of Granitic Rocks. Journal of Petrology, 25, 956-983. http://dx.doi.org/10.1093/petrology/25.4.956

[24] Sun, S.S and McDonough, W.F. (1989) Chemical and Isotopic Systematic of Oceanic Basalts: Implication for Mantle Composition and Processes. In: Saunder, A.D. and Norry, M.J., Eds., Magmatism in the Ocean Basins, Vol. 42, Geological Society, Special Publications, London, 313-345. http://dx.doi.org/10.1144/GSL.SP.1989.042.01.19

[25] Jung, S. and Hellebrand, E. (2007) Textural, Geochronological and Chemical Constraints from Polygenetic Titanite and Monogenetic Apatite from a Mid-Crustal Shear Zone: An Integrated EPMA. Geosciences, 65, 108-125. (In Persian 
with English Abstract) http://dx.doi.org/10.1016/j.chemgeo.2007.01.029

[26] Parák, T. (1975) Kiruna Iron Ores Are Not “Intrusive-Magmatic Ores of the Kiruna Type”. Economic Geology, 70, 1242-1258. http://dx.doi.org/10.2113/gsecongeo.70.7.1242

[27] Frietsch, R. (1978) On the Magmatic Origin of Iron Ores of the Kiruna Type. Economic Geology, 73, 478-485. http://dx.doi.org/10.2113/gsecongeo.73.4.478

[28] Frietsch, R. and Perdahl, J.A. (1995) Rare Earth Elements in Apatite and Magnetite in Kirunatype Iron Ores and Some Other Iron Ore Types. Ore Geology Reviews, 9, 489-510. http://dx.doi.org/10.1016/0169-1368(94)00015-G

[29] Hildebrand, R.S. (1986) Kiruna-Type Deposits: Their Origin and Relationship to Intermediate Subvolcanic Plutons in the Great Bear Magmatic Zone, Northwest Canada. Economic Geology, 81, 640-659. http://dx.doi.org/10.2113/gsecongeo.81.3.640

[30] Yu, J.J., Chen, Y.C., Mao, J.W., Pirajno, F. and Duan, C. (2011) Review of Geology, Alteration and Origin of Iron Oxide-Apatite Deposits in the Cretaceous Ningwu Basin, Lower Yangtze River Valley, Eastern China: Implications for Ore Genesis and Geodynamic Setting. Ore Geology Reviews, 43, 170-181. http://dx.doi.org/10.1016/j.oregeorev.2011.07.008

[31] Helvaci, C. (1984) Apatite-Rich Iron Deposits of the Avnik (Bing l) Region, Southeastern Turkey. Economic Geology, 79, 354-371. http://dx.doi.org/10.2113/gsecongeo.79.2.354

[32] Förster, H. and Knittel, U. (1979) Petrographic Observation on a Magnetite Deposit at Mishdovan, Central Iran. Economic Geology, 74, 1485-1489. http://dx.doi.org/10.2113/gsecongeo.74.6.1485

[33] Naslund, H.R., Henriquez, F., Nystroem, J.O., Vivallo, W. and Dobbs, F.M. (2002) Magmatic Iron Ores and Associated Mineralisation: Examples from the Chilean High Andes and Coastal Cordillera. In: Porter, T.M., Ed., Hydrothermal Iron Oxide Copper-Gold and Related Deposits: A Global Perspective, Volume 2, PGC Publishing, Adelaide, 207-226.

[34] Torab, F.M. and Lehmann, B. (2007) Magnetite-Apatite Deposits of the Bafq District, Central Iran: Apatite Geochemistry and Monazite Geochronology. Mineralogical Magazine, 71, 347-363. http://dx.doi.org/10.1180/minmag.2007.071.3.347

[35] Chen, H.Y., Clark, A.H., Kyser, T.K., Ullrich, T.D., Baxter, R., Chen, Y.M. and Moody, T.C. (2010) Evolution of the Giant Marcona-Mina Justa Iron Oxide-Copper-Gold District, South-Central Peru. Economic Geology, 105, 155-185. http://dx.doi.org/10.2113/gsecongeo.105.1.155

[36] Chen, H.Y., Clark, A.H. and Kyser, K.T. (2010b) The Marcona Magnetite Deposit, Ica, South-Central Peru: A Product of Hydrous, Iron Oxide-Rich Melts? Economic Geology, 105, 1441-1456. http://dx.doi.org/10.2113/econgeo.105.8.1441

[37] Ioannis, M. and Maria, E.E. (2001) Occurrence of Apatite Associated with Magnetite in an Ophiolite Complex (Othrys), Greece. American Mineralogist, 86, 1143-1150. http://dx.doi.org/10.2138/am-2001-1003

[38] Sillitoe, R.H. and Burrows, D.R. (2002) New Field Evidence Bearing on the Origin of the El Laco Magnetite Deposit, Northern Chile. Economic Geology, 97, 1101-1109.

[39] Maniar, P.D. and Piccoli, P.M. (1989) Tectonic Discrimination of Granitoids. Geological Society of America Bulletin, 101, 635-643. http://dx.doi.org/10.1130/0016-7606(1989)101<0635:TDOG>2.3.CO;2

[40] Pearce, J.A., Stern, R.J., Bloomer, S.H. and Fryer, P. (2005) Geochemical Mapping of the Mariana Arc-Basin System: Implications for the Nature and Distribution of Subduction Components. Geochemistry, Geophysics, Geosystems, 6, Article ID: Q07006. http://dx.doi.org/10.1029/2004gc000895 


\section{Submit or recommend next manuscript to SCIRP and we will provide best service for you:}

Accepting pre-submission inquiries through Email, Facebook, LinkedIn, Twitter, etc.

A wide selection of journals (inclusive of 9 subjects, more than 200 journals)

Providing 24-hour high-quality service

User-friendly online submission system

Fair and swift peer-review system

Efficient typesetting and proofreading procedure

Display of the result of downloads and visits, as well as the number of cited articles

Maximum dissemination of your research work

Submit your manuscript at: http://papersubmission.scirp.org/ 